\title{
A differenciált árazással kapcsolatos ösztönzőkről
}

Differenciált árazás esetében ugyanazért a termékért vagy szolgáltatásért az igénybevétel időpontjától függően eltérő árat kell fizetni. A tanulmány áttekinti az ezzel kapcsolatban felmerülő legfontosabb kérdéseket (fogyasztói alkalmazkodás, kapacitáskihasználtság), valamint az aktuálisan adható közgazdasági válaszokat. Megmutatjuk, milyen körülmények között vezet Pareto-javuláshoz a csúcsidei árazás bevezetése, majd különböző fogyasztási szokásokat feltételezve vizsgáljuk a vállalat ösztönzöttségét a differenciált árazásra. Az eredmények azt mutatják, hogy a vállalat ösztönzői lehetnek technológiai jellegüek és keresletoldaliak is. A fogyasztók pedig annál jobban járnak, minél rugalmasabban tudnak alkalmazkodni. Az alkalmazkodást segítő módszerek (megbízható ár-összehasonlító oldalak, olcsó okosmérők stb.) könnyebb elérhetősége érdekében szabályozói beavatkozásra is szükség lehet.* Journal of Economic Literature (JEL) kód: L12, L50, L90.

\section{Bevezetés}

Differenciált árazással az iparágak változatos és rendkívül hosszú sorában találkozhatunk, a turizmustól kezdve a távközlésen át az áramszolgáltatásig. Az a tény, hogy gyakorlatilag ugyanazért a szolgáltatásért más összeget kell fizetni délelőtt és délután, télen és nyáron vagy nappal és éjszaka, közgazdasági szempontból igen fontos kérdéseket vet fel. Milyen körülmények között éri meg a vállalatnak másképp árazni egyes időszakokban? Mi alapján válassza meg az időszakokat, és milyen árat szabjon? Az egységestől eltérő árazás kialakításával a szolgáltató elvileg képes kiküszöbölni a kereslet szabályos ingadozásait. De nem éppen a vállalat árpolitikája okozza-e a keresletingadozást? Amellett, hogy a megfelelö díjcsomagok és árkategóriák kialakításával a vállalat képes növelni

* A szerző köszönetet mond Valentiny Pálnak és a cikk névtelen lektorának értékes észrevételeikért. Jelen publikáció az Európai Unió, Magyarország és az Európai Szociális Alap társfinanszírozása által biztosított forrásból, az EFOP-3.6.3-VEKOP-16-2017-00007 azonosítószámú, „Tehetségből fiatal kutató - A kutatói életpályát támogató tevékenységek a felsőoktatásban" címü projekt keretében jött létre.

Antal-Pomázi Krisztina, KRTK Közgazdaság-tudományi Intézet és Budapesti Corvinus Egyetem

(e-mail: antal-pomazi@krtk.mta.hu).

A kézirat első változata 2019. november 13-án érkezett szerkesztőségünkbe.

DOI: http://dx.doi.org/10.18414/KSZ.2020.3.244 
rendelkezésre álló kapacitásának kihasználtságát, megéri-e vajon a fogyasztóknak is a változás? Mely esetekben vezet a csúcsidei árazás a jólét növekedéséhez, netán az árak csökkenéséhez? Létezik-e a fogyasztók és a vállalat tulajdonságainak olyan együttállása, amely mellett az időszakok eltérö árazása kölcsönösen előnyös a felek számára? Szükséges vagy érdemes-e ösztönözni a differenciált árazás bevezetését? Tanulmányunkban ezekhez hasonló kérdésekre keressük a választ.

A következőkben megvizsgáljuk, milyen piaci sajátosságok ösztönzik a differenciált árazás bevezetését. Áttekintjük az ezekkel kapcsolatban felmerülő közgazdasági kérdéseket. Megnézzük, hogy milyen körülmények között jelent Pareto-javulást a csúcsidei árazás bevezetése, és különbözö fogyasztási szokásokat feltételezve vizsgáljuk a vállalat ösztönzöttségét a csúcsidei árazás bevezetésére. Végül eredményeinket összegezzük.

\section{Differenciált árazás a keresleti oldalon}

A differenciált árazás lényege, hogy ugyanazért a termékért vagy szolgáltatásért az igénybevétel időpontjától függően eltérő árat kell fizetni. Olyan iparágakban célszerü alkalmazni, ahol a kereslet időben periodikusan változik, vagy a szükséges kapacitás fenntartásának költsége a vállalat teljes költségeinek nagy hányadát teszi ki (például a turizmus, áramszolgáltatás, távközlés, közlekedés stb. esetében). Bár a termék látszólag ugyanaz (repülöút Budapeströl Barcelonába, telefonhívás valamely viszonylatban), a kereslet fluktuációja abból következik, hogy a fogyasztók számára a szolgáltatás a különböző időpontokban (repülöút télen vagy nyáron, telefonhívás nappal vagy éjszaka) eltérö értéket jelent. Legtöbbször fennáll valamilyen helyettesíthetőség az egyes időszakok között. Ha a fogyasztók könnyen tudnak alkalmazkodni az árakhoz, akkor rugalmasságuk révén nyerhetnek a csúcsidei árazással: aki hajlandó hajnalban kimenni a repülötérre vagy szilveszter éjszakáján utazni, az ugyanúgy eljut az úti céljába, de több pénze marad másra.

Fogyasztói csoportok viselkedésében is találhatunk eltéréseket. A meghatározott tulajdonságok (életkor, vállalatméret stb.) szerint elkülönülö, eltérő értékelésekkel és árérzékenységgel rendelkező vásárlókkal szemben a vállalat optimális viselkedése más és más. Egyes csoportok könnyebben képesek alkalmazkodni, így az ő kiszolgálásukkal nem nyerhet annyit a szolgáltató, mint a rugalmatlan fogyasztókéval. A háztartások például könnyen időzíthetik mosogatógépüket, hogy csak éjszaka induljon el, míg egy pékségnek sokkal költségesebb kiváltania a hajnali energiafelhasználást.

\section{A kínálati oldal sajátosságai}

A tipikusan ingadozó keresletủ iparágakban a fogyasztói oldal sajátos viselkedéséhez legtöbbször társul a kapacitás problémája. A kapacitásba való beruházás (egy erőmű megépítése, új repülőgép beszerzése, új kifutópálya építése és ezek fenntartása) általában jelentős részét teszi ki a vállalkozás költségeinek, ami egyúttal 
belépési korlátot is jelent a potenciális versenytársak számára. A termelés maximuma a rendelkezésre álló kapacitástól függ, a kapacitásra vonatkozó döntést tehát a magasabb keresletủ időszak figyelembevételével hozzák meg. Emiatt a kibocsátás növelése a csúcsidőszakban drágább, mint az alacsony keresletü időszakban, ahol egy pótlólagos egység megtermelése nem igényel többletkapacitást. A villamos energia esetében például a zsinóráram termelésének alacsony a határköltsége, ami többszörösére nő, ha egy „csúcserőmüvet” kell bekapcsolni (Joskow-Wolfram [2012] 381. o.). Ha egy ilyen piacon a fogyasztók időszaktól független áron vásárolhatnak, akkor csúcsok idején - amikor a határköltség magasabb az árnál - túl sokat fognak fogyasztani. A társadalmilag optimálistól eltérö fogyasztási szerkezet pedig a társadalmilag optimálistól eltérő beruházásokhoz vezet (uo. 382. o.). A termelési költségbeli különbségek tehát indokolhatják az időszakok eltérö árazását. A jobb kapacitáskihasználás okozta hatékonyságnövekedés miatt kívánatos „ugyanazt” a terméket eltérő árakon értékesíteni. Például egy légitársaság jobban jár, ha 50 euróért adja el az utolsó néhány helyet egy repülőjáraton, mint ha egyáltalán nem értékesíti. Általánosságban érvényes, hogy adott időpontban az optimális ár annál alacsonyabb, minél több szabad hely van még, és adott kapacitásfelesleg esetén az optimális ár időben csökkenő (Escobari [2009] 60. o.).

Más oldalról megközelítve a problémát, a vállalat éppen az eltérő árazás segítségével képes szabályozni a fogyasztást: a fogyasztókat (amennyiben számukra az eltérő időszakbeli termékek helyettesíthetők egymással) ide-oda „terelheti” az időszakok között. A kereslet „simítása” különösen fontos olyan piacokon, ahol az extrém túlkereslet a rendszer összeomlásához vezethet. A 2000-2001-es kaliforniai áramválság egyik kiváltó oka is az volt, hogy a fogyasztók nem érzékelték a fogyasztás és az árak közötti összefüggést (Faruqui-Earle [2006] 24. o.). Hosszabb távon pedig, a gazdaság növekedésével, a csúcsidőszaki zsúfoltság gyakoribbá válása várható. Kanadában például a 2008-as válság előtt, 2003-2007 között a csúcsidei kereslet már gyorsabban nőtt, mint a teljes áramfelhasználás (Rowlands [2008] 8. o.). A hálózat stabilitása miatt is kívánatos tehát a csúcsidei felhasználás egy részét alacsonyabb keresletü időszakokra terelni. Amerikai kísérletek azt mutatják, hogy a teljes áramfogyasztás dinamikus árazás mellett sem csökken, csak átütemeződik. Az emberek nagy része hajlandó elviselni azt a kellemetlenséget, hogy nem fogyaszthat a preferenciái szerint (például 2 fokkal melegebb van nyáron a szobában, mint amit a légkondicionálón eredetileg beállított), ha ezzel elkerülhető a rendszer összeomlása. Kívánatos azonban meghagyni a túlfogyasztás lehetőségét, így azok, akik nem tudnak lemondani keresletükről (például betegek, és rosszul vannak a melegtől), továbbra is megkapják a szükséges mennyiséget (Newsham-Bowker [2010] 3294. o.).

Minél rugalmatlanabbak a fogyasztók, minél kevésbé helyettesítik egymással a különböző időszakok fogyasztásait, annál tökéletesebben képes a vállalat árdiszkriminációt megvalósítani az időszakok között. Az árdiszkrimináció révén növelhető a profit, a diszkrimináló vállalat ugyanis olyan „személyre szabott”, a fogyasztási preferenciákat tükröző árakat alkalmaz, amelyekkel a fogyasztói többlet nagyobb hányadát képes megszerezni. Ez a profitnövekmény ösztönözheti a vállalatot a csúcsidei árazás bevezetésére. 
A fogyasztók alkalmazkodási képességét jelentősen növelhetik a megfelelő technológiai eszközök (például okosmérők), amelyek segítségével elöre beállított válaszokat adhatnak az árváltozásokra, hogy ne kelljen folyton manuálisan beavatkozniuk. Ezek felszerelése jelentős költséggel jár, de leolvasásuk már nem igényel többleterőforrást, ami komoly megtakarítást jelent a hagyományos rendszerekhez képest (Faruqui-Earle [2006] 26. o.). Nagy-Britanniában például, ahol már döntöttek a villamosenergia- és gázfogyasztás okosmérőinek felszereléséről, a kormányzat becslése szerint nagyjából öt évbe telne, amíg a hatások a háztartások energiaszámláinak a csökkenéséhez vezetnek. Feltéve, hogy az energiapiaci verseny kellően intenzív, a mérők létesítésének költsége az átállás idején növeli ugyan az árakat, de később, a megtakarítások realizálásakor az árak csökkennek, és az előnyök a fogyasztókhoz jutnak (NAO [2018] 42. o.). A brit számvevőszék azonban arra is rámutatott, hogy a megtérülési becslés különösen érzékeny arra, milyen mértékủ energiamegtakarítást (azaz fogyasztáscsökkentést) feltételeznek (uo. 74. o.).

\section{A differenciált árazás hatásainak közgazdasági elemzése}

Annak ellenére, hogy a dinamikus árazás keresleti és kínálati oldalon is a jólét növekedésével járhat, mégsem nevezhető általános gyakorlatnak. Az Egyesült Államokban például a villamos energia piacán még 2010-ben is a háztartásoknak kevesebb mint 1 százaléka fizetett időben változó árak alapján (FERC [2011] 98-99. o.). 2011 végére ugyan több mint 20 millió okosmérőt szereltek fel (a háztartások körülbelül 13 százaléka), a dinamikus árazás ennél lassabb ütemben terjedt el (Joskow-Wolfram [2012] 383. o.). A repülőtéri zsúfoltságot kezelő megoldásokat áttekintve Nagy [2012] rámutat arra, hogy Európában általánosan elterjedt módszer a résidőkiosztás, a szakirodalom álláspontja azonban az, hogy „a zsúfoltsági [azaz csúcsidei] árazáson alapuló keresletszabályozási módszer hatékonyabban szünteti meg vagy csökkenti a zsúfoltságot” (85. o.).

Az energiapiacon a mérés problémája - ami korábban komoly ellenvetésnek számított a dinamikus árazással szemben - a technikai haladás révén mára megoldottnak látszik. Két további ellenérvet szoktak felhozni, ami megfontolást igényel. Az egyik a fogyasztók alkalmazkodási képessége, a másik az árazás megváltozása révén megvalósuló újraelosztás.

A dinamikus árazást a villamos energia piacán bevezető programokat számos tanulmány értékelte (lásd például Faruqui-Sergici [2010], Newsham-Bowker [2010], Wolak [2010], Faruqui-Wood [2008]). Az eredmények alapján indokolatlannak tünnek azok az aggodalmak, amelyek szerint a fogyasztók nem képesek vagy hajlandók bonyolult vagy gyorsan változó árstruktúrához alkalmazkodni. A legtöbb programot úgy tervezték, hogy az átlagos fogyasztó ugyanannyit fizessen, mint korábban, akkor is, ha nem változtat a fogyasztási szokásain. A háztartások azonban így is szignifikánsan (árazási sémától függően 3-44 százalékkal) csökkentették fogyasztásukat a csúcsidőszakokban. Az eredmények alapján a fogyasztók jobban reagálnak a nagyobb árkülönbségekre, de csökkenő mértékben. Azok, akiknek a megfelelö technológia is 
rendelkezésére állt (például automata termosztát, ami rendkívüli csúcs esetén magasabb hőmérsékletre állítja be a légkondicionálót), jelentősen nagyobb, akár kétszeres megtakarítást is elérhettek (Newsham-Bowker [2010] 3293-3294. o., FaruquiEarle [2006] 25. o., Faruqui-Sergici [2010] 221. o.). Annak ellenére megváltoztatták a fogyasztási szokásaikat, hogy az áramszámla a vizsgált tagállamokban viszonylag kis hányadát adja a rezsiköltségeknek (Faruqui-Earle [2006] 24. o.). Mivel azonban a termelés határköltsége csúcsidöben meredeken emelkedik, a kínálati oldalon már kis keresletcsökkenés is jelentős megtakarításhoz vezet (Faruqui-Sergici [2010] 195. o.). Úgy tünik tehát, hogy alaptalan a fogyasztók alkalmazkodási képességére vonatkozó aggodalom. Sőt az elkötelezettebb fogyasztói csoportok okosmérő nélkül is csökkentik csúcsidöszaki fogyasztásukat (Newsham-Bowker [2010] 3294. o.), így egy őket célzó program még költséghatékonyabb.

Azt azonban nem lehet figyelmen kívül hagyni, hogy a fogyasztók alkalmazkodási képessége különböző. Kérdés, hogy van-e ebben a különbözöségben rendszer? Van-e szisztematikus eltérés egyes fogyasztói csoportok között, és milyen tulajdonságok alapján? Ez a kínálati oldal számára is fontos információ, hiszen a vállalatnak az az érdeke, hogy „beazonosítsa” a fogyasztókat, és minél jobban elkülönítse a fogyasztási mintázatokat. Ha olyan termékről van szó, amelyet a társadalom széles rétegei fogyasztanak (például földgáz, áram), akkor az árazás a politika számára is fontos kérdéssé válhat. Ha az ár minden időszakban egyforma, akkor azok a fogyasztók, akiknek viszonylag egyenletes a fogyasztása, keresztfinanszírozzák azokat, akiknek a fogyasztása változékonyabb. Ha megváltoznak az árak, és a csúcsidőszak ára többszöröse lesz a csúcsidőn kívülinek, akkor azok járnak jobban, akiknek rugalmasabb a kereslete. Magyarországon például a földgáz esetében a legszegényebbeket valószínűleg nem érintené az árváltozás, mert ők nem gázzal fütenek. Az áram esetén elképzelhető, hogy azok járnak a legjobban, akik a fogyasztásuk nagy részét az elektromos autójuk töltésére vagy a medencéjük fütésére használják. Erről azonban egyelöre nem áll rendelkezésre megfelelö mennyiségü adat. Borenstein [2013] két szolgáltató adatait elemezte az Egyesült Államokban. Azt vizsgálta, hogy különböző árazási sémák mellett mely háztartásoknak hogyan változna az éves áramszámlája. Eredményei alapján a dinamikus árazás hatása a lakóhely szerint különbözik leginkább. Jövedelmük szerint csoportosítva a háztartásokat, nincs különbség az egyes csoportoknál mutatkozó változásban. Nem volt tehát igazolható az a vélekedés, hogy az alacsony jövedelmü háztartásokat rosszabbul érintené a dinamikus árazás bevezetése. Az alacsony fogyasztású háztartások jobban jártak, mint a magas fogyasztásúak, de a különbség nem volt jelentős. A vizsgált tényezők közül legnagyobb hatása az időjárásnak - és így a földrajzi elhelyezkedésnek - volt. A tengerparti területek jobban jártak az áttéréssel, mivel a fogyasztásuknak nagyobb hányada esik a csúcsidőn kívülre, míg a belső területeken élők számlái emelkedtek. Csakhogy a magasabb jövedelműeknek nagyobb hányada él a tengerparton, így végül is ök jártak jobban.

A redisztribúció mértéke a rugalmasságon múlik, ennek heterogenitását azonban kevesen vizsgálták. Wolak [2010] egy másik programot értékelve azt találta, hogy az alacsony jövedelmü háztartások rugalmasabban alkalmazkodnak, és így nagyobb megtakarítást érhetnek el dinamikus árazás mellett, mint a magas 
jövedelműek. Kaliforniai adatokon a CRA [2005] ennek ellenkezőjére jutott: a magas keresetủek nagyobb mértékben csökkentették a fogyasztásukat, mint az alacsony keresetűek. Feltehetően ők több olyan eszközt használnak, amelyek rugalmasan időzíthetők (légkondicionáló, elektromosautó-töltés, medencefütés), míg például az elektromos tüzhelyet használók vagy a többszemélyes háztartások rugalmatlanabbul alkalmazkodtak (74. o.).

A közismert modellek nagy része a szabályozott monopólium árazási problémájával foglalkozik. A fejlett országok egy részében azonban a hagyományosan vertikálisan integrált vállalatokból álló iparágakban mára megtörtént a piacnyitás, a korábbi nagyvállalatok feldarabolása, hálózatos iparágakban a hálózat tulajdonosi leválasztása. Emiatt nem beszélhetünk tipikusan szabályozott monopóliumokról a csúcsidei árazást alkalmazó iparágakban. Az sem mondható azonban, hogy a versenyzői környezet valamilyen formájának megteremtésével a vállalatok piaci ereje eltünt volna.

Közelebbről megvizsgálva ezeket a piacokat, általában azt találjuk, hogy a piaci erő a fogyasztók preferenciái, illetve korlátozott racionalitása miatt maradhat meg. Például ha két város között csak egy légitársaság kínál közvetlen járatot, de van lehetöség átszállással is utazni (ami hosszabb időt vesz igénybe), akkor azok az utasok, akik sokra értékelik a szabadidejüket, rugalmatlanul válaszolnak a közvetlen járat árának emelkedésére. Ha sok ilyen utas van azon a viszonylaton, akkor velük szemben a vállalat mintegy monopolistaként viselkedhet. Új belépők megjelenése ilyen piacokon - éppen a fent tárgyalt, kapacitással kapcsolatos problémák miatt - csak hosszú távon várható, például ha a potenciális utasok száma megnő az adott viszonylaton annyira, hogy jövedelmező legyen két közvetlen járatot üzemeltetni. Az energiapiacokon hasonlóképpen megfigyelhető, hogy bár több szereplö van, és van közöttük verseny, a vállalatok lokálisan piaci erővel rendelkeznek (Joskow-Wolfram [2012] 382. o., CMA [2016] 38-39. o., Valentiny [2019] 121. o., Borenstein-Holland [2005]).

Érdemes néhány szót szólni a fogyasztói döntésekben megfigyelhető torzításokról is, amelyeken a racionálistól való szisztematikus eltérést értjük. Az emberek érzékenyebbek a veszteségekre, mint a nyereségekre, ezért hajlamosak a status quónál maradni akkor is, ha valójában lenne jobb lehetőségük. Gyakran a „bevált” szolgáltatójuknál maradnak annak ellenére, hogy egy másik cég ajánlata valójában kedvezöbb lenne. Valentiny [2019] olyan piacokra mutat példákat, ahol a fogyasztók többsége az inkumbens szolgáltatónál maradt akár évekkel a piacnyitás után is (126. o.). A vállalatok jelentős haszonra tehetnek szert, ha a fogyasztók viselkedési sajátosságait kihasználva magasan tudják tartani az árakat. Az Egyesült Királyságban például 2012-2015 között a hat legnagyobb energiaszolgáltató együtt évente átlagosan 1,4 milliárd fontot keresett így (CMA [2016] 45. o.).

A fogyasztók döntését nehezíti továbbá, ha sokféle lehetőség közül kell választani, vagy ha az ajánlatok bonyolultak. Utóbbi tulajdonság ösztönzi a vállalatokat, hogy minél bonyolultabb(nak látszó) termékeket, szerződéseket vagy tarifarendszereket kínálva összezavarják a fogyasztókat, akik így (veszteségkerülésük miatt) nem váltanak szolgáltatót (Walker [2017] 7. o.). Ezt támasztják alá az Egyesült Királyság versenyhivatalának (Competition and Markets Authority, CMA) energiapiaci tapasztalatai is. Felmérésükben a 7000 megkérdezett háztartás közül a válaszadók 
56 százaléka még soha nem váltott szolgáltatót, vagy nem is tudta, hogy válthatna, és 72 százaléka soha nem váltott tarifát a szolgáltatójánál, vagy nem is tudta, hogy válthatna (CMA [2016] 22. o.). Az Európai Unióban 2009-2015 között a villamos energia és a földgáz piacán is évente átlagosan a fogyasztók körülbelül 5 százaléka váltott szolgáltatót. Az országok több mint negyedében a váltási arány 1 százaléknál is alacsonyabb volt (EC [2017] 28. o.).

$\mathrm{Az}$ „inaktív” fogyasztókkal szemben a vállalat kihasználhatja piaci erejét, és jóval magasabb áron értékesíthet, mint amit költségei indokolnak (CMA [2016] 39. o.). A fogyasztók „tehetetlensége" ráadásul oly módon is csökkenti a versenyt, hogy egy új belépőnek nehéz piacot szereznie. A CMA ezért többek között azt javasolta, hogy a szabályozó hozzon létre egy adatbázist az inaktív fogyasztókról, amit a versenytársak felhasználhatnak arra, hogy kedvezö ajánlatokat tegyenek (uo. 53. o.).

Szabályozói szempontból azok a piacok lényegesek, ahol a dinamikus árazáshoz alkalmazkodó fogyasztás valamilyen közjószágot hoz létre. Ilyen például a villamos energia esetében a rendszer stabilitása. Ha az ehhez szükséges okosmérők felszerelése akkora költséggel jár, hogy a szolgáltatónak önmagában nem éri meg, ráadásul a fogyasztók rövidlátók, és kevéssé hajlanak olyan beruházásokra, melyek csak 5-10 éven belül térülnek meg, akkor érdemes lehet beavatkozni. A döntés meghozatalához azonban körültekintő költség-haszon elemzésre van szükség. Az Európai Bizottság számára készült összehasonlító (benchmarking) jelentés azt mutatja, hogy több országban is negatív a megtérülés (Tractebel [2019]), de a számítási módszerek nagyon különbözők. Elképzelhető, hogy a beruházás csak kellően magas penetráció mellett térül meg, de az is lehetséges, hogy nem érdemes minden fogyasztói csoportot okosmérőkkel ellátni. A döntési anomáliákra való tekintettel valószínủ, hogy a háztartások esetében érdemes kötelezővé tenni a dinamikus tarifára váltást.

A csúcsidei árazás elemzésére sok modell született már, amelyek eltérő feltételezésekkel élnek a termelési költségekre, kapacitásköltségekre, fogyasztói preferenciákra és helyettesíthetőségre vonatkozóan. Legtöbbjük szabályozott monopólium árazási problémájával foglalkozik, főként az áramszolgáltatási iparágban. A sokat hivatkozott Bailey-White [1974] olyan monopólium viselkedését vizsgálta, amelynek piacán két keresleti időszak különböztethető meg. A két időszak kereslete lineáris, és független egymástól. A társadalmilag hatékony megoldás a határköltség-alapú árazás: az alacsony keresletű időszakban csak az előállítás határköltségét fizetik a fogyasztók, a magas keresletüben pedig az előállítás és a kapacitásfenntartás határköltségének összegét. Amennyiben a szóban forgó vállalat természetes monopólium (azaz átlagköltsége csökkenő), a kétrészes árképzés biztosíthatja a társadalmilag hatékony megoldást. A cikk sokat hivatkozott eredménye, hogy rámutat, mely esetekben van ösztönözve a vállalat az időszakok fordított árazására (lásd például Joskow [1976], Bergstrom-MacKie-Mason [1991], Shy [1995]). A monopólium növelheti profitját a magas keresletü időszak alacsony árain keresztül, ha ez a kereslet rugalmas, vagy ha a megtérülési rátás szabályozás miatt abban érdekelt, hogy minél nagyobb kapacitást tartson fenn indokolhatóan. Az ilyen helyzetek létezése azonban többnyire magukból a modellfeltevésekböl adódik. Az árazás „megfordulása” amiatt következik be, hogy a keresletek árrugalmassága eltérö. A monopóliumnak viszont éppen 
azért van lehetősége „lefölözni” a rugalmatlan kereslet hasznait, mert nem engedjük meg azt a lehetőséget, hogy a fogyasztók máskor fogyasszanak, ha az általuk elsődlegesen preferált időszak drága. Bergstrom-MacKie-Mason [1991] azzal a kérdéssel foglalkozott, hogy mi történik, ha egy szabályozott megtérülési rátájú monopóliumnak lehetősége nyílik áttérni az egységes árról (uniform pricing) csúcsidei árazásra, miközben a megtérülési ráta változatlan marad. Az eredmények azt mutatják, hogy ha a helyettesítési rugalmasság kellően nagy, a két időszak eltérő árazásával mindkét ár csökkenni fog. A fogyasztói többlet így biztosan nő, miközben a vállalat profitja sem csökken. Kijelenthetjük tehát, hogy ez a megoldás társadalmi szempontból kívánatos. A következőkben felépítjük a csúcsidei árazás egy általánosabb modelljét, és megvizsgáljuk, milyen következtetéseket vonhatunk le a kibővített verzióból a fent említett, több megszorító feltételt tartalmazó modellekhez képest.

\section{A csúcsidei árazás általánosabb modellje}

A következő oldalakon bemutatott általánosabb modell sok feltevésében hasonlít az elözőkre, ugyanakkor néhány lényeges tulajdonságában eltér tőlük. Elsősorban a csúcsidei árazás jóléti hatásainak feltárását tartjuk szem előtt. A szabályozott megtérülési rátájú monopólium kitételének feloldása után kérdés, hogy bekövetkezik-e olyan eset, amikor biztosan mindenki jól jár. Vizsgálatunk tárgya egy olyan vállalat, amely a fogyasztókkal szemben piaci erővel rendelkezik (lokális monopólium), és termékét két időszakban, eltérő határköltségekkel állítja elő: nappal $(D)$ és éjszaka $(N)$. A kapacitásra vonatkozó döntés egy magas és egy alacsony keresletủ időszakra szól. A fogyasztók választhatnak, hogy mikor veszik igénybe a szolgáltatást: nappal, éjszaka vagy mindkét időszakban.

A csúcsidei árazást először úgy vezetjük be, hogy a vállalat profitja ne csökkenjen. Az energiapiacokon bevezetett dinamikus árazási projektek nagy részét így tervezték: a szolgáltató várható profitja ne csökkenjen, és az átlagos fogyasztó éves áramszámlája is változatlan maradjon, ha nem változtat a fogyasztási szokásain. Ez nem feltétlenül vezet a dinamikus árazással elérhető legjobb eredményhez, de biztosan Pareto-javulást jelent, ha az árak csökkennek, miközben a vállalat profitja változatlan marad. Annál valószínübb, hogy a fogyasztók jól járnak a csúcsidei árazás bevezetésével, minél rugalmasabban képesek helyettesíteni egymással a két idöszak fogyasztásait. Eredményeink összegzéseként kimondhatjuk a következő tételt [a bizonyítást lásd a Függelék A) részében].

1. TÉTEL • Egy konstans határköltségekkel termelö, szolgáltatását két különbözö idöszakban nyújtó lokális monopólium áttérése az egységes árazásról csúcsidei árazásra, a profit változatlansága mellett, mindkét idöszak árainak csökkenését eredményezi, amennyiben a fogyasztók helyettesitési rugalmasságára igaz a következö két feltétel:

1. feltétel: $\sigma>\frac{p_{N}}{p_{N}-c_{N}}$ 
és

2. feltétel: $\sigma>\frac{p_{N}\left(1-\varepsilon_{N}\right)-1}{\frac{p_{D} x_{D}}{x_{N}}-1}$, ahol

$p_{D}$ és $p_{N}$ az egyes időszakok árai, $x_{D}$ és $x_{N}$ a fogyasztásuk, $c_{D}$ és $c_{N}$ a szolgáltatás nyújtásának egységköltsége idöszakok szerint, továbbá $\rho=\frac{p_{D}}{p_{N}}, \varepsilon_{N}=\frac{\rho}{x_{N}} \frac{\partial x_{N}}{\partial \rho}, X=\frac{x_{D}}{x_{N}}$ és $\sigma(\rho)=-\frac{\partial \ln X(\rho)}{\partial \ln \rho}$

\section{A vállalat helyzete, döntési problémája}

Az előzőekben beláttuk, milyen feltételek teljesülése esetén vezet a csúcsidei árazásra való áttérés mindkét időszak árainak csökkenéséhez, azaz a fogyasztói többlet növekedéséhez, miközben a kérdéses vállalat profitja azonos szinten marad. Vajon a szabályos ingadozást mutató kereslettel szembesülő vállalatnak érdekében áll-e differenciáltan árazni az egyes időszakokat? Növekszik-e a profit az árarány megváltoztatásával, és ha igen, milyen körülmények között? A következőkben ezekre a kérdésekre keressük a választ. Megvizsgáljuk a vállalat döntési problémáját, azaz hogy mi az optimális árszint és árstruktúra a nyereség növelése szempontjából. Kérdésünk a továbbiakban az, hogy a fogyasztók milyen tulajdonságai mellett jár jobban a vállalat a csúcsidei árazással az egységes árhoz képest.

Az általunk vizsgált vállalat továbbra is két időszakban kínálja szolgáltatását, nappal $(D)$ és éjszaka $(N)$. Az egyes időszakokban a termék előállításának egységköltsége és az egységnyi kapacitás fenntartásának költsége konstans. A kapacitásra vonatkozó döntés két egymást követő, különböző keresletű időszakra szól. A rendelkezésre álló kapacitásnál több fogyasztót nem lehet kiszolgálni. Feltételezzük, hogy a csúcsidei árazás bevezetésével a nappali időszak kereslete lesz magasabb, ezért (mivel kihasználatlan kapacitást fenntartani fölösleges kiadás) a kapacitás is a nappali kereslethez fog igazodni. Az egyszerüség kedvéért egyelőre feltesszük azt is, hogy a vállalat egyetlen típusú fogyasztót szolgál ki. A fogyasztók egyformák, keresleti függvényük legyen nulladfokban pozitív homogén. A vásárlók ily módon nem a konkrét árak, hanem az árarány megváltozására érzékenyek.

Minél rugalmasabb mindkét időszakban a kereslet, annál kisebb árréssel tud müködni optimumban a vállalat [lásd a Függelék B) részét]. Ha az egyik időszakra vonatkozóan rugalmasan helyettesítenek a fogyasztók (érzékenyek az időszak árának változására), a másikban pedig rugalmatlanok, akkor a rugalmas keresletű időszak árrésének növeléséhez a rugalmatlan időszak árrésének nagymértékü csökkentésére (akár határköltség alatti árazására) van szükség. Ilyen eset, amikor a csúcsidei ár változására reagáló helyettesítés nem ugyanazon szolgáltatás másik időszakbeli igénybevételével történik, hanem valamely más helyettesítő termék révén. Például ha csúcsidőben drága a földgáz, az ilyen típusú fogyasztók inkább fával fütenek; ha júliusban 
drága a repülöjegy, akkor sokan nem szeptemberben mennek nyaralni, hanem az általuk tervezett időpontban autóval vagy vonattal. Effajta viselkedés természetesen akkor lehetséges, ha viszonylag alacsony költségen rendelkezésre állnak közeli helyettesítő termékek (cserépkályha, tűzifa, autó stb.). Az áramszolgáltatást például rövid távon valószínüleg költséges más termékekkel helyettesíteni, de hosszú távon megvalósítható egy üzem energiafelhasználásának átstrukturálása vagy akár a saját eszközökkel történő áramtermelés is.

Általánosságban tehát azt mondhatjuk, minél kevésbé érzékenyen reagálnak a fogyasztók adott időszak árának megváltozására, annál nagyobb árrést alkalmazhat a vállalat ennek az időszaknak az árazásakor. Fordítva pedig, minél rugalmasabbak, annál kisebb lesz az optimális árrés. A továbbiakban többféle feltevéssel élünk a fogyasztói preferenciákra vonatkozóan, és azt vizsgáljuk, érdemes-e a vállalatnak adott körülmények között differenciáltan árazni az időszakokat.

\section{Lineáris eset}

A gyakorlatban számos piacon elöfordul, hogy egy termék vagy szolgáltatás vásárlóinak körében elkülöníthetők olyan csoportok, amelyek tagjai a csoporton belül egymáshoz hasonlóan viselkednek, a csoportok fogyasztási szokásai, mintázata azonban eltér egymástól (például háztartások és vállalatok, idősek és fiatalok stb.). Az ilyen csoportok szerint történő sikeres árdiszkrimináció növeli a vállalatok profitját, tehát a vállalatok ösztönözve vannak a fogyasztási különbségek feltárására, a „személyre szabott" árazás (díjcsomagok) kialakítására. Emiatt a csúcsidei árazással kapcsolatos ösztönzők (megéri-e a vállalatnak) vizsgálata során számba kell vennünk a több csoportnak történő értékesítés lehetőségét.

Tekintsünk két fogyasztói csoportot (1. és 2.), keresletük legyen nulladfokban pozitív homogén és az árarányban lineáris, azaz $x_{D}^{i}=A_{i} \frac{p_{D}^{i}}{p_{N}^{i}}+T_{i}$ és $x_{N}^{i}=B_{i} \frac{p_{D}^{i}}{p_{N}^{i}}+M_{i}$ $(i=1,2)$ alakú, ahol $A_{i}<0, T_{i}>0, B_{i}>0$ és $M_{i}>0$. Ilyen függvényformák mellett a fogyasztók vásárlási szokásait elsődlegesen az árarány megváltozása befolyásolja, ezért tekinthetjük az árarányt a vállalat döntési változójának.

A vállalat akkor járhat jobban a két csoport megkülönböztetésével, ha két különbözö díjcsomagot (éjszakai és nappali árpárost) tud nekik ajánlani. Az egyszerüség kedveért tegyük fel, hogy olyan csoportokkal állunk szemben, amelyeket a vállalat is képes megkülönböztetni egymástól. (Például a vállalkozónak igazolnia kell, hogy létezik a vállalkozása, a diáknak fel kell mutatnia diákigazolványát, a bizonyos életkornál fiatalabbaknak/idősebbeknek pedig a személyi igazolványukat.) Ekkor a két csoport kereslete független egymástól, a másik csoportnak szabott áraktól. ${ }^{1}$ A csúcsidei árazás előnyös volta így a két csoportra külön vizsgálható. Most két feltétel teljesülésére van szükség:

\footnotetext{
${ }^{1}$ Itt nem vizsgáljuk azt a kérdést, hogy a másik csoportnak felajánlott árak esetleg annyival kedvezőbbnek tűnnek, hogy ösztönzőket teremtenek a típusok „álcázására”, például a diákigazolvány hamisítására vagy a vállalati kedvezménykártya magáncélú használatára.
} 
$A_{1}\left(c_{D}+r-2 \rho_{1}\right) \leq B_{1}\left(1-c_{N}\right)+T_{1} \quad$ és $\quad A_{2}\left(c_{D}+r-2 \rho_{2}\right) \leq B_{2}\left(1-c_{N}\right)+T_{2}$.

Ezek nagyon hasonlók az egy fogyasztói csoportos esethez, mivel a vállalat (a keresletek függetlensége miatt) lényegében csoportonként határozza meg az optimális árarányt. Feltéve, hogy a vállalat legalább az éjszakai termelésben nem veszteséges, az egyen lötlenségek jobb oldala pozitív, a bal oldalon pedig $A_{i}<0$. Ezért amennyiben $c_{D}+r-2 \rho_{i}$ nem negatív, az egyenlőtlenségek biztosan teljesülnek. Az egységes árazás azt jelenti, hogy az árarány, $\rho=1$. Ehhez képest akkor éri meg (bármelyik csoportban) biztosan növelni $\rho$-t, ha $c_{D}+r-2 \geq 0$.

Amennyiben tehát a nappali termelés vagy a kapacitás fenntartásának költsége kellően nagy (tipikusan az utóbbi valószínü), mindkét csoportnak megéri csúcsidei árazást ajánlani, fogyasztói tulajdonságaiktól (keresletüktől) függetlenül, mivel azt a technológia önmagában indokolja. Ezenkívül akkor is megéri csúcsidei árazást alkalmazni, ha a technológiai adottságok ugyan nem teszik szükségessé, a fogyasztói adottságok viszont lehetővé teszik (például ha $A$ abszolút értékben kis szám, azaz az adott fogyasztói csoport tagjai viszonylag érzéketlenek az árváltozások iránt). Az egyes csoportok fogyasztásainak sajátár-rugalmasságától függően az is elöfordulhat, hogy az egyik csoportnak érdemes csúcsidei árazást ajánlani, míg a másiknak nem. A lineáris esetet összegezve kimondhatjuk a következő tételt:

2. TÉTEL • A nulladfokban pozitív homogén keresleti függvénnyel rendelkezö, az áraránytól lineárisan függö keresletü egy vagy több fogyasztói csoportot kiszolgáló lokális monopóliumnak biztosan érdekében áll csúcsidei árazást alkalmazni adott csoporttal szemben 1. technológiai okokból, amennyiben a kapacitás fenntartásának határköltsége vagy a csúcsidőszaki termelés egységköltsége kellöen magas, vagy 2. keresleti okokból, amennyiben a csoport tagjainak csúcsidőszaki fogyasztása viszonylag rugalmatlan, azaz a fogyasztók csak kismértékben reagálnak az ár növekedésére a kereslet csökkentésével.

\section{Arányos árérzékenység}

Annak érdekében, hogy robusztusabb eredményeket kapjunk, másfajta fogyasztói viselkedést feltételezve is megvizsgáljuk a csúcsidei árazás lehetőségét. Olyan keresleti függvényekkel végezzük az elemzést, amelyekre igaz, hogy két különböző időszak keresleteinek azonos ár szerinti deriváltjai egymás konstansszorosai. Visszatérünk továbbá az egyetlen fogyasztói csoport vizsgálatához is az elemzés egyszerüsítése érdekében.

A vásárlók mindkét ár megváltozására érzékenyek, de a nappali időszak árának módosulására a nappali kereslet valószínüleg (általában) nagyobb mértékben reagál, mint az éjszakai, ezért feltételezzük, hogy $\frac{\partial x_{D}}{\partial p_{D}}=a \frac{\partial x_{N}}{\partial p_{D}}$, ahol $a<-1$. Ugyanígy az éjszakai időszak árára is érzékenyebb a saját kereslete, mint a nappali időszaké, ezért 
$\frac{\partial x_{N}}{\partial p_{N}}=b \frac{\partial x_{D}}{\partial p_{N}}$, ahol $\mathrm{b}<-1$. A termelési technológia azonos az előzőkben tárgyalttal, és feltesszük, hogy nappal lesz a csúcsidőszak.

Ebben, a fogyasztók különböző időszakbeli keresleteinek azonos ár szerinti árérzékenységeit egymás konstansszorosának feltételező elemzési keretben ismét megállapíthatjuk, hogy a monopólium mozgásterét nagymértékben befolyásolják a fogyasztók tulajdonságai. Az alkalmazható árrések a fogyasztók alkalmazkodási képességeitől (árérzékenységüktől) függnek. Eredményeinket a 3. TÉTELBEN foglalhatjuk össze, a bizonyítást lásd a Függelék $C$ ) részében.

3. TÉTEL • A csúcsidei árazást alkalmazó, két időszakban eltérö árakon értékesitő lokális monopólium mindkét időszakban pozitív árrést fog alkalmazni. Az optimális árak tartományának elhelyezkedését a termelési költségek, valamint a fogyasztói helyettesités mértékét kifejezö, az árérzékenységek közötti kapcsolatot mutató a és b paraméterek értékei határozzák meg a következöképpen: az árakra $|a|>\frac{p_{N}-c_{N}}{p_{D}-c_{D}-r}>\left|\frac{1}{b}\right|$-nek
kell teljesülnie.

\section{Összefoglalás}

A differenciált árazás az azt alkalmazó vállalat számára több szempontból is elönyös: javítja a kapacitáskihasználtságot, és növeli a profitot. Elemzésünk során sikerült formálisan megmutatni, milyen körülmények között növeli a vállalat nyereségét az egységes árazásról a csúcsidei árazásra való áttérés. Általában kétféle körülmény ösztönözheti a változtatást: 1 . a technológia, azaz a magas kapacitásfenntartási vagy termelési költségek (amelyek közül az előbbi igen gyakori az ingadozó keresletű iparágakban) és 2 . a fogyasztók tulajdonságai, azaz a csúcsidőszaki fogyasztás alacsony árrugalmassága.

Minél rugalmatlanabbul reagálnak a vásárlók az árváltozásokra, annál jobban tudja ezt a vállalat kihasználni profitja növelése céljából. Ezzel szemben a fogyasztók éppen akkor járnak jól a csúcsidei árazással, ha elég rugalmasan tudnak váltani az időszakok között. A vállalat érdeke tehát többnyire ellentétes a fogyasztók érdekeivel. Elemzésünk során sikerült megmutatni, milyen körülmények között létezik az egyéni tulajdonságoknak olyan kombinációja, amely esetében a csúcsidei árazás egyaránt kívánatos mindkét fél szempontjából. A kérdéses feltételek fennállása esetén az árstruktúra megváltoztatása társadalmi szempontból Pareto-javuláshoz vezet. A közismert modellek ezen a téren meglehetösen sok egyszerüsítő feltevéssel élnek (helyettesítésre képtelen fogyasztók, nulla határköltséggel termelő vállalat, szabályozott megtérülési rátájú monopólium). Emiatt szükség volt a meglévő modellek bizonyos irányú kibővítésére általánosabb érvényü következtetések levonása érdekében. A kiterjesztés során igyekeztünk úgy eljárni, hogy kiküszöböljük a már ismert hibákat, miközben lehetőleg megtartjuk az előnyös tulajdonságokat. A fenti elemzési keretben kijelenthetjük, hogy létezik a fogyasztók és a lokális 
monopólium tulajdonságainak olyan együttese, amely mellett a csúcsidei árazás mindkét fél számára kölcsönösen elönyös, a vállalat pedig általában ösztönözve van a csúcsidei árazás bevezetésére. A fogyasztók annál jobban járnak, minél rugalmasabban tudnak alkalmazkodni. Ebben komoly segítséget jelenthetnek a technológiai újítások, mint például az okosmérők. Ezek felszerelése egyelőre viszonylag költséges (a szolgáltató számára csak nagyjából a költségek fele térül meg megtakarítások formájában), ezért szükséges lenne, hogy a terhek egy részét a fogyasztók viseljék. Ha azonban ők nem kellően előrelátók, vagy a korlátozott racionalitás más módon akadályozza elköteleződésüket, akkor a szabályozónak indokolt lehet beavatkoznia a jólét növelése érdekében. Egyes piacokon a differenciált árazásra adott keresleti válasz társadalmi szintű haszonnal is jár: az árampiacon például növeli a rendszer stabilitását. Minél könnyebben elérhetők lesznek az alkalmazkodást segítő technológiák (megbízható ár-összehasonlító oldalak, olcsó okosmérők stb.), annál jobban járhat mindenki a dinamikus árazással.

\section{Hivatkozások}

BAiley, E. E.-White, L. J. [1974]: Reversals in Peak and Offpeak Prices. The Bell Journal of Economics and Management Science, Vol. 5. No. 1. 75-92. o. https://doi.org/10.2307/3003093.

Bergstrom, T.-MacKie-Mason, J. K. [1991]: Some Simple Analytics of Peak-Load Pricing. The RAND Journal of Economics, Vol. 22. No. 2. 241-249. o. https://doi. org/10.2307/2601020.

Borenstein, S. [2013]: Effective and Equitable Adoption of Opt-In Residential Dynamic Electricity Pricing. Review of Industrial Organization, Vol. 42. 127-160. o. https://doi. org/10.1007/s11151-012-9367-3.

Borenstein, S.-Holland, S. [2005]: On the efficiency of competitive electricity markets with time-invariant retail prices. RAND Journal of Economics, Vol. 36. No.3. 469-493. o. https://doi.org/10.3386/w9922.

CMA [2016]: Energy market investigation. Summary of final report. Competition and Markets Authority, London, https://assets.publishing.service.gov.uk/government/uploads/system/ uploads/attachment_data/file/531157/Energy-final-report-summary.pdf.

CRA [2005]: Impact Evaluation of the California Statewide Pricing Pilot. Final Report. Charles River Associates, https://www.smartgrid.gov/files/Impact_Evaluation_California_ Statewide_Pricing_Pilot_200501.pdf.

EC [2017]: Second Report on the State of the Energy Union. Commission Staff Working Document. Monitoring progress towards the Energy Union objectives - key indicators. $\operatorname{COM}(2017) 53$ final. European Commission, Brüsszel, február 1. https://ec.europa.eu/ commission/sites/beta-political/files/2nd-report-state-energy-union_en.pdf.

EsCOBARI, D. [2009]: Systematic peak-load pricing, congestion premia and demand diverting: Empirical evidence. Economics Letters, Vol. 103. No. 1. 59-61. o. https://doi.org/10.1016/j. econlet.2009.01.019.

Faruqui, A.-Earle, R. [2006]: Demand Response and Advanced Metering. Regulation, Spring, 24-27. o. https:/www.cato.org/sites/cato.org/files/serials/files/regulation/2006/3/ v29n1-3.pdf.

FARUQui, A.-SERgicI, S. [2010]: Household Response to Dynamic Pricing of Electricity: A Survey 
of 15 Experiments. Journal of Regulatory Economics, Vol. 38. No. 2. 193-225. o. https://doi. org/10.1007/s11149-010-9127-y.

FARUQUi, A.-Wood, L. [2008]: Quantifying the benefits of dynamic pricing in the mass market. Edison Electric Institute Report, prepared by The Brattle Group. https:// www.smartgrid.gov/files/Quantifying_Benefits_Dynamic_Pricing_in_Mass_ Market_200812.pdf.

FERC [2011]: 2010 Assessment of Demand Response and Advanced Metering. Staff Report. Federal Energy Regulatory Commission, http://www.ferc.gov/legal/staff-reports/2010dr-report.pdf.

Joskow, P. L. [1976]: Contributions to the Theory of Marginal Cost Pricing. The Bell Journal of Economics, Vol. 7. No. 1. 197-206. o. https://www.jstor.org/stable/3003196.

Joskow, P. L.-Wolfram, C. D. [2012]: Dynamic Pricing of Electricity. American Economic Review: Papers \& Proceedings, Vol. 102. No. 3. 381-385. o. https://doi.org/10.1257/ aer.102.3.381

Nagy Benedek [2012]: A repülőtéri zsúfoltságkezelési módszerek hatékonysága. Közgazdasági Szemle, 59. évf. 1. sz. 74-91. o.

NAO [2018]: Rolling out smart meters. Report by the Comptroller and Auditor General. National Audit Office, Department for Business, Energy \& Industrial Strategy, https:// www.nao.org.uk/wp-content/uploads/2018/11/Rolling-out-smart-meters.pdf.

Newsham, G. R.-Bowker, B. G. [2010]: The effect of utility time-varying pricing and load control strategies on residential summer peak electricity use: A review. Energy Policy, Vol. 38. No. 7. 3289-3296. o. https://doi.org/10.1016/j.enpol.2010.01.027.

Rowlands, I. H. [2008]: Demand Response in Ontario: Exploring the Issues. Prepared for the Independent Electricity System Operator (IESO). http://www.theimo.com/imoweb/pubs/ marketreports/omo/2009/demand_response.pdf.

Shy, O. [1995]: Industrial Organization. The MIT Press, Cambridge, MA.

TraCtebel [2019]: European smart metering benchmark. Benchmarking smart metering deployment in the EU-28. Revised Final Report. https://www.vert.lt/SiteAssets/teises-aktai/ EU28\%20Smart\%20Metering\%20Benchmark\%20Revised\%20Final\%20Report.pdf.

VALENTINY PÁL [2019]: Verseny a hálózatos szolgáltatások kiskereskedelmi piacán. Megjelent: Valentiny Pál-Nagy Csongor István-Berezvai Zombor (szerk.): Verseny és szabályozás, 2018. MTA KRTK Közgazdaságtudományi Intézet, Budapest, 116-140. o. https://www.mtakti. hu/wp-content/uploads/2019/03/Vesz2018_06_ValentinyP_halozat.pdf.

WALKER, M. [2017]: Behavioural economics: the lessons for regulators. European Competition Journal, Vol. 13. No. 1. 1-27. o. https://doi.org/10.1080/17441056.2017.1298338.

Wolak, F. [2010]: An Experimental Comparison of Critical Peak and Hourly Pricing: The PowerCentsDC Program. https://pdfs.semanticscholar.org/ f678/09f69f24305f3f647543911b163147d820e4.pdf.

\section{Függelék}

A) Az 1. TÉTEL BIZONYíTÁSA • A lokális monopólium profitfüggvénye $\pi=p_{D} x_{D}+$ $+p_{N} x_{N}-c_{D} x_{D}-c_{N} x_{N}-r \max \left\{x_{D}, x_{N}\right\}$ alakú, ahol $p_{D}$ és $p_{N}$ az egyes időszakok árai, $x_{D}$ és $x_{N}$ a fogyasztásuk, $c_{D}$ és $c_{N}$ a szolgáltatás nyújtásának egységköltsége időszakok szerint, $r$ pedig egységnyi kapacitás fenntartásának költsége. A kapacitásra vonatkozó döntés 
egy magas és egy alacsony keresletű időszakra szól. A fogyasztók választhatnak, hogy mikor veszik igénybe a szolgáltatást: nappal, éjszaka vagy mindkét időszakban. A vásárlók egyformák, hasznossági függvényük legyen konkáv és $U_{i}\left[y^{i} ; f\left(x_{D}^{i}, x_{N}^{i}\right)\right]$ alakú, ahol $y^{i}$ az $i$-edik fogyasztó fogyasztása minden másból (numeraire), $x_{D}^{i}$ a vállalat termékének nappali fogyasztása, $x_{N}^{i}$ pedig az éjszakai. Az $f$ függvény homotetikus és szigorúan kvázikonkáv. Emiatt az $i$-edik fogyasztó helyettesítési határaránya $(M R S)$ szigorúan monoton csökkenő függvénye lesz az $i$-edik $X=\frac{x_{D}^{i}}{x_{N}^{i}}$ fogyasztási aránynak (Bergstrom-MacKie-Mason [1991] 242. o.). Definiáljuk az $X(\rho)$ függvényt implicit módon a következő összefüggéssel: $\operatorname{MRS}[X(\rho)]=\rho$. Az $X(\rho)$ tehát a nappali fogyasztás éjszakaihoz viszonyított optimális aránya, amennyiben az árarány $\rho$.

A vásárlók helyettesítési képességét, hajlandóságát fejezi ki a két időszak fogyasztása közötti helyettesítési rugalmasság: $\sigma(\rho)=-\frac{\partial \ln X(\rho)}{\partial \ln \rho}$. Az árarány növekedése kétféleképpen mehet végbe: a nappali fogyasztás árának növekedésével vagy az éjszakai árának csökkenésével. Mindkét esemény egyformán hat az egyes időszakok fogyasztásaira, ha azok helyettesíthetők egymással. Ebből következően az általunk $\sigma$-val jelölt érték biztosan pozitív. Egységes árazás esetén $\rho=1$. $\mathrm{Ha} \frac{\partial p_{D}}{\partial \rho}<0$, akkor a csúcsidei árazás bevezetésével mindkét időszak árai csökkenni fognak. Mivel a vállalat izoprofit-egyenesén kívánunk mozogni, a profitfüggvényt mint összefüggést felhasználhatjuk a vizsgálathoz. Kifejezhetjük $p_{D}$-t a profit adott konstans $\pi$ szintje mellett: $p_{D}=\left(c_{D}+r+c_{N} \frac{x_{N}}{x_{D}}+\pi \frac{1}{x_{D}}\right) \theta_{D}$, ahol $\theta_{D}$ a nappali szolgáltatásra költött pénz aránya a szolgáltatásra költött összegen belül: $\theta_{D}=\frac{p_{D} x_{D}}{p_{D} x_{D}+p_{N} x_{N}}$. Hasonlóképpen nevezzük az éjszakai szolgáltatásra költött összeg arányát $\theta_{N}$-nek. Felhasználva az összefüggést, miszerint $\theta_{N}=1-\theta_{D}$ és $\frac{x_{N}}{x_{D}} \theta_{D}=\rho \theta_{N}$, a következő alakra hozhatjuk a $p_{D}$-t kifejezö egyenletet: $p_{D}=\left(c_{D}+r-c_{N} \rho\right) \theta_{D}+c_{N} \rho+\pi \frac{1}{x_{D}} \theta_{D}$. A $\rho$ szerint differenciálva és mindkét oldalt $\frac{\rho}{p_{D}}$-vel megszorozva a következő alakot kapjuk:

$\frac{\partial \ln p_{D}}{\partial \ln \rho}=\left(c_{D}+r-c_{N} \rho\right) \frac{\rho}{p_{D}} \frac{\partial \theta_{D}}{\partial \rho}+c_{N}\left(1-\theta_{D}\right) \frac{\rho}{p_{D}}+\pi \frac{\partial\left(\frac{p_{D}}{p_{D} x_{D}+p_{N} x_{N}}\right)}{\partial \rho}$.

A további átalakítások során fel kell használnunk a következő lemmát:

1. LEMMA $\bullet \frac{\partial \ln \theta_{D}}{\partial \ln \rho}=\theta_{N}[1-\sigma(\rho)]$. 
Bizonyítás • X és $\rho$ definícióját felhasználva:

$\theta_{D}=\frac{p_{D} x_{D}}{p_{D} x_{D}+p_{N} x_{N}}=\frac{\rho X}{\rho X+1}=1-\frac{1}{\rho X+1}$, ezért $\frac{\partial \theta_{D}}{\partial \rho}=\frac{1}{(\rho X+1)^{2}}\left(X+\rho \frac{\partial X}{\partial \rho}\right)$.

Némi átalakítással megkapható a keresett összefüggés:

$\frac{\partial \ln \theta_{D}}{\partial \ln \rho}=\frac{1}{(\rho X+1)^{2}}\left(X+\rho \frac{\partial X}{\partial \rho}\right) \frac{\rho X+1}{X}=\frac{1-\sigma(\rho)}{\rho X+1}=\theta_{N}[1-\sigma(\rho)]$, q. e. d. Visszatérve az eredeti problémára, $\frac{\partial \ln \theta_{D}}{\partial \ln \rho}$ behelyettesítése és újabb átalakítások után
az alábbi alakhoz jutunk:

$\frac{\partial \ln p_{D}}{\partial \ln \rho}=\theta_{N}\left(1-\sigma \frac{p_{N}-c_{N}}{p_{N}}\right)-\theta_{N}^{2} \frac{1}{p_{N} x_{N}} \pi(1-\sigma)+\pi \frac{\partial\left(\frac{p_{D}}{p_{D} x_{D}+p_{N} x_{N}}\right)}{\partial \rho}$.

Ennek a három tagból álló kifejezésnek kellene negatívnak lennie ahhoz, hogy a csúcsidei árazás bevezetése társadalmi szinten biztosan Pareto-javuláshoz vezessen. Feltételezve, hogy a költségek pozitívak, a vállalat profitja pedig hosszú távon nem negatív, és bevezetve az $\varepsilon_{N}=\frac{\rho}{x_{N}} \frac{\partial x_{N}}{\partial \rho}$ jelölést, néhány átalakítás után a Pareto-
javulás általános feltétele: $\left(p_{D} x_{D}+p_{N} x_{N}\right)\left(\sigma \frac{p_{N}-c_{N}}{p_{N}}-1\right)+\pi\left(\sigma p_{D} X-\sigma+1\right)+\pi p_{N}\left(\varepsilon_{N}-1\right)>0$.

Ebből már látható, hogy a Pareto-javulás eléréséhez az 1. TÉTELBEN szereplő egyenlőtlenségeknek kell teljesülniük.

B) A vállalat döntési Problémája - A profitfüggvény $\pi=p_{D} x_{D}\left(p_{D}, p_{N}\right)+$ $+p_{N} x_{N}\left(p_{D}, p_{N}\right)-c_{D} x_{D}\left(p_{D}, p_{N}\right)-c_{N} x_{N}\left(p_{D}, p_{N}\right)-r \max \left\{x_{D}\left(p_{D}, p_{N}\right), x_{N}\left(p_{D}, p_{N}\right)\right\}$ alakú, ahol $p_{D}$ és $p_{N}$ az egyes időszakokárai, $x_{D}$ és $x_{N}$ pedig a fogyasztásuk, $c_{D}$ és $c_{N}$ a szolgáltatás nyújtásának egységköltsége időszakok szerint, $r$ pedig az egységnyi kapacitás fenntartásának költsége. Ekkor a profitmaximum eléréséhez két feltétel teljesülésére van szükség:

$\frac{\partial \pi}{\partial p_{D}}=x_{D}+\frac{\partial x_{D}}{\partial p_{D}}\left(p_{D}-c_{D}-r\right)+\frac{\partial x_{N}}{\partial p_{D}}\left(p_{N}-c_{N}\right)=0$

és

$\frac{\partial \pi}{\partial p_{N}}=x_{N}+\frac{\partial x_{D}}{\partial p_{N}}\left(p_{D}-c_{D}-r\right)+\frac{\partial x_{N}}{\partial p_{N}}\left(p_{N}-c_{N}\right)=0$.

Mivel a fogyasztók helyettesíthetik egymással a két időszak fogyasztását, $x_{D}$ és $x_{N}$ függ $p_{D}$-től és $p_{N}$-töl is. Így az optimumfeltételekben mind a négyféle elsőrendü parciális derivált szerepel. A deriváltak között az Euler-tétel segítségével teremthetünk kapcsolatot. Az alábbi két feltételt kapjuk: 
$\frac{\partial x_{N}}{\partial p_{N}} \frac{p_{N}}{p_{D}}\left(p_{N}-c_{N}\right)=x_{D}+\frac{\partial x_{D}}{\partial p_{D}}\left(p_{D}-c_{D}-r\right)$

és

$x_{N}+\frac{\partial x_{N}}{\partial p_{N}}\left(p_{N}-c_{N}\right)=\frac{\partial x_{D}}{\partial p_{D}} \frac{p_{D}}{p_{N}}\left(p_{D}-c_{D}-r\right)$.

Ebből az alakból jól látszik, hogy a határköltségen való árazás $\left(p_{N}-c_{N}=0\right.$ és $p_{D}-c_{D}-r=0$ ), amire adott esetben a szabályozó törekszik, nem lehet optimális a vállalat szempontjából. Ez nem meglepő, hiszen utóbbi a saját profitja és nem a társadalmi jólét maximalizálására törekszik. Az (F3) egyenletet az (F4)-gyel elosztva, bevezetve az $\varepsilon_{x_{N}}=\frac{\partial x_{N}}{\partial p_{N}} \frac{p_{N}}{x_{N}}$ és $\varepsilon_{x_{D}}=\frac{\partial x_{D}}{\partial p_{D}} \frac{p_{D}}{x_{D}}$ jelöléseket a sajátár-rugalmasságra, a következő feltételt kapjuk:

$\varepsilon_{x_{N}} \times \frac{p_{N}-c_{N}}{p_{N}}+\varepsilon_{x_{D}} \frac{p_{D}-c_{D}-r}{p_{D}}=-1$.

Látható, hogy a vállalat szempontjából az árazás akkor optimális, ha az egyes időszakok sajátár-rugalmasságainak és árréseinek szorzatösszege pontosan -1. Feltéve, hogy a szóban forgó termék normál jószág, $\varepsilon_{x_{D}}$ és $\varepsilon_{x_{N}}$ is negatív.

C) A 3. TÉTEL BIZONYÍTÁSA • A vállalat profitfüggvénye: $\pi=p_{D} x_{D}+p_{N} x_{N}-c_{D} x_{D}-$ $-c_{N} x_{N}-r \max \left\{x_{D}, x_{N}\right\}$.

Feltesszük, hogy nappal lesz a csúcsidőszak, vagyis $\max \left\{x_{D}, x_{N}\right\}=x_{D}$.

A vállalat most már két változó szerint optimalizál, így a differenciált árazás mellett a profitmaximum szükséges feltételei:

$\frac{\partial \pi}{\partial p_{D}}=x_{D}+p_{D} \frac{\partial x_{D}}{\partial p_{D}}+p_{N} \frac{\partial x_{N}}{\partial p_{D}}-\left(c_{D}+r\right) \frac{\partial x_{D}}{\partial p_{D}}-c_{N} \frac{\partial x_{N}}{\partial p_{D}}=0$

és

$\frac{\partial \pi}{\partial p_{N}}=x_{N}+p_{N} \frac{\partial x_{N}}{\partial p_{N}}+p_{D} \frac{\partial x_{D}}{\partial p_{N}}-\left(c_{D}+r\right) \frac{\partial x_{D}}{\partial p_{N}}-c_{N} \frac{\partial x_{N}}{\partial p_{N}}=0$.

Felhasználva az árérzékenységre vonatkozó feltevéseinket, némi átalakítás után a következő formákat nyerjük:

$x_{D}+\frac{\partial x_{N}}{\partial p_{D}}\left[a\left(p_{D}-c_{D}-r\right)+p_{N}-c_{N}\right]=0$

és

$x_{N}+\frac{\partial x_{D}}{\partial p_{N}}\left[p_{D}-c_{D}-r+b\left(p_{N}-c_{N}\right)\right]=0$.

A két kifejezés nagyon hasonlít egymásra. Az első tag $\left(x_{D}\right.$ és $\left.x_{N}\right)$ és a zárójel előtt álló szorzó (a kereszt-árérzékenység) mindkettőben pozitív ( $x_{D}$ és $x_{N}$ egymás helyettesítői). 
A profitmaximum eléréséhez így mindkét időszakban az szükséges, hogy a zárójelben lévő kifejezések negatívak legyenek. Ebből a két feltételből az is rögtön látható, hogy a határköltséggel megegyező (jólét-maximalizáló) ár a vállalat szempontjából nem lehet optimális.

Amennyiben a nappali értékesítés nyereséges, az éjszakainak is nyereségesnek kell lennie, de kisebb mértékben, ${ }^{2}$ méghozzá úgy, hogy a fenti két feltétel egyszerre teljesülhessen. Ha pedig optimumban az éjszakai időszakban nyereséges a vállalat, az kizárja, hogy a nappaliban ne legyen az.

Azt is tudjuk, mely egyenlőtlenségek teljesülése szükséges a profitmaximumhoz: az elsőrendü feltételekben szereplő zárójeles tagoknak kell negatívnak lenniük. Optimumban tehát az $a\left(p_{D}-c_{D}-r\right)+p_{N}-c_{N}<0$ és $p_{D}-c_{D}-r+b\left(p_{N}-c_{N}\right)<0$ összefüggéseknek kell fennállniuk. A kettőből együttesen következik, hogy

$|a|>\frac{p_{N}-c_{N}}{p_{D}-c_{D}-r}>\left|\frac{1}{b}\right|$-nek

kell teljesülnie. A vállalat szempontjából optimális, az elsőrendű feltételeket kielégítő éjszakai és nappali ár kombinációkat az F1. ábra szemlélteti.

F1. ábra

A vállalat számára optimális ártartomány a $p_{D}-p_{N}$ síkon

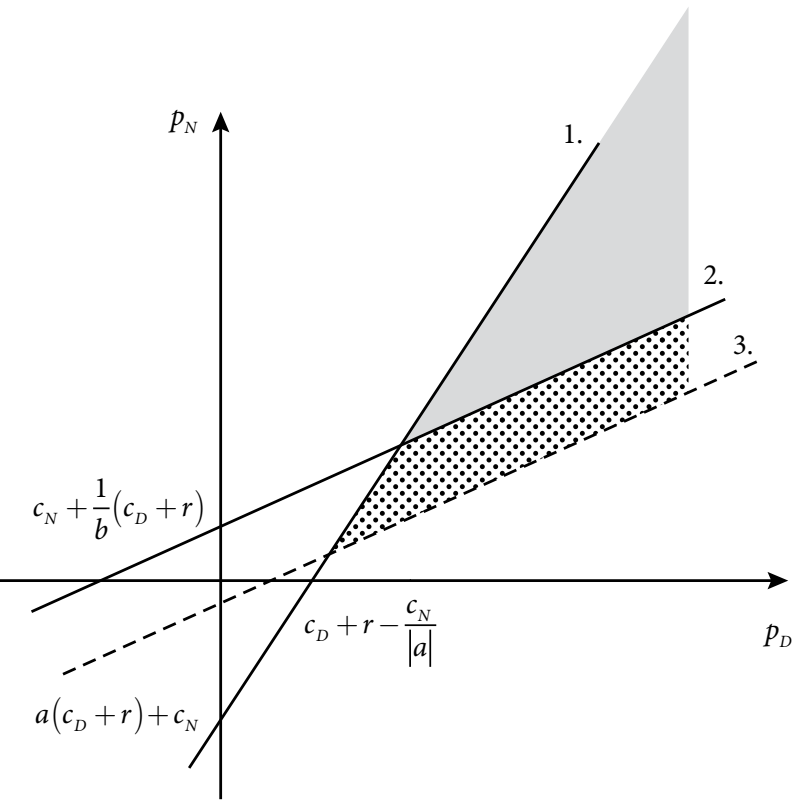

\footnotetext{
${ }^{2} \mathrm{Az} a$ és $b$ is negatív, ezért ha a vállalat a nappali időszakban veszteséges, az éjszakaiban még inkább annak kell lennie a feltételek teljesüléséhez, és fordítva (ezek az esetek azonban várhatóan nem maximum-, hanem minimumhelyei a profitfüggvénynek).
} 
A lehetséges árakat a $p_{D}-p_{N}$ síkon ábrázolva, az 1. számú egyenes mutatja az első, az $a\left(p_{D}-c_{D}-r\right)+p_{N}-c_{N}<0$ feltételt. Az egyenlötlenség értelmében az optimális $p_{D}-p_{N}$ pároknak ez alatt az egyenes alatt kell elhelyezkedniük. ${ }^{3}$

A második, a $p_{D}-c_{D}-r+b\left(p_{N}-c_{N}\right)<0$ feltételt a 2., illetve a 3. számú egyenesekkel ábrázolhatjuk. ${ }^{4}$ A második feltétel akkor teljesül, ha a vállalat által választott $p_{D}$ és $p_{N}$ árakat jelképező pont a megfelelö (a 2. vagy 3. számú) egyenes fölött helyezkedik el.

Az optimális árak tartománya az előzőek értelmében $|b|>\frac{c_{D}+r}{c_{N}}$ esetén az F1. ábrán szürkével jelölt, 1. és 2. számú egyenesek között fekvő terület. Az $|b|<\frac{c_{D}+r}{c_{N}}$ esetben ez a tartomány kibővül a pöttyökkel jelölt résszel az 1. és 3. számú egyenesek között fekvő területté.

${ }^{3}$ Az egyenes meredeksége pozitív. A $p_{N}$ tengely és az 1 . számú egyenes metszéspontja a $\left(p_{D} ; p_{N}\right)=$ $=\left[0 ; a\left(c_{D}+r\right)+c_{N}\right]$ pontban van, amelynek második koordinátája $a<-1$ és $c_{N}<c_{D}$ miatt biztosan negatív.

${ }^{4} \mathrm{Az}$ egyenesek meredeksége pozitív, és „laposabbak”, mint az 1. számú egyenes. A függőleges tengelymetszet a $\left(p_{D} ; p_{N}\right)=\left[0 ; c_{N}+\frac{1}{b}\left(c_{D}+r\right)\right]$ pontban van, amelynek második koordinátája $b$ értékétől függően lehet pozitív vagy negatív. Amennyiben $-b>\frac{c_{D}+r}{c_{N}}$, a tengelymetszet pozitív, és a feltétel a 2. számú egyenessel reprezentálható. Ellenkező esetben a pont a negatív tartományba esik, és a második feltételt jelképező egyenes elhelyezkedése a 3. számúéhoz hasonló. 